\title{
AGRONOMIC PERFORMANCE OF ROCKET AS A FUNCTION OF PHOSPHORUS FERTILISATION IN A P-RICH SOIL ${ }^{1}$
}

\author{
CAMILA SENO NASCIMENTO ${ }^{2}$, CAROLINA SENO NASCIMENTO ${ }^{2}$, \\ ARTHUR BERNARDES CECÍLIO FILHO ${ }^{2 *}$
}

\begin{abstract}
In intensive vegetable production systems, it is natural to increase nutrient contents in the soil due to the frequent fertiliser applications, especially phosphorus $(\mathrm{P})$. There are few studies on the response of vegetables to phosphate fertilisation under such conditions. In this context, the objective of this study was to evaluate the agronomic performance of rocket as a function of phosphorus fertilisation in a P-rich Rhodic Eutrudox soil. Five $\mathrm{P}$ doses $\left(0,50,100,200\right.$, and $\left.300 \mathrm{~kg} \mathrm{ha}^{-1} \mathrm{P}_{2} \mathrm{O}_{5}\right)$ were evaluated in a randomised complete block design with four replicates. Maximum soil $\mathrm{P}$ content and shoot $\mathrm{P}$ content at harvest were obtained at a dose of $300 \mathrm{~kg} \mathrm{ha}^{-1} \mathrm{P}_{2} \mathrm{O}_{5}$. Rocket responded negatively to $\mathrm{P}$ fertilisation. The increase of $\mathrm{P}$ doses promoted the decrease of height and yield of the crop.
\end{abstract}

Keywords: Eruca sativa. Phosphate fertilisation. Mineral nutrition. Productive efficiency.

\section{DESEMPENHO AGRONÔMICO DA RÚCULA EM FUNÇÃO DA ADUBAÇÃO COM FÓSFORO EM SOLO COM ELEVADO TEOR DO NUTRIENTE}

RESUMO - Em sistemas intensivos de cultivo de hortaliças é natural o aumento de teores de nutrientes no solo devido às frequentes aplicações de fertilizantes, em especial de fósforo (P). Existem poucos estudos sobre a resposta das olerícolas à fertilização fosfatada nessas condições. Nesse contexto, o presente estudo teve como objetivo avaliar o desempenho agronômico da rúcula em função da adubação fosfatada em Latossolo com elevado teor do nutriente. Cinco doses de $\mathrm{P}\left(0,50,100,200\right.$ e $300 \mathrm{~kg}^{-1}$ de $\left.\mathrm{P}_{2} \mathrm{O}_{5}\right)$ foram avaliados em delineamento de blocos ao acaso com quatro repetições. Máximo teor de $\mathrm{P}$ no solo e teor de $\mathrm{P}$ na parte aérea na colheita foram obtidos com a aplicação de $300 \mathrm{~kg} \mathrm{ha}^{-1}$ de $\mathrm{P}_{2} \mathrm{O}_{5}$. A rúcula respondeu negativamente à adubação fosfatada. $\mathrm{O}$ aumento das doses de $\mathrm{P}$ promoveu redução da altura e produtividade da cultura.

Palavras-chave: Eruca sativa. Adubação fosfatada. Nutrição Mineral. Eficiência produtiva. 


\section{INTRODUCTION}

In the last few years, rocket has been conquering new markets and increasing its prevalence among vegetables (CHUN et al., 2017). In 2017, in Brazil, according to the Companhia de Entrepostos e Armazéns Gerais de São Paulo, 4,104 tons of rocket were sold (CEAGESP, 2017). However, despite the growing demand by the population for this leafy green, there are few studies related to this crop, especially regarding the management of phosphate fertilisation, a factor that represents a great amount of the production costs, considering that Brazil imports more than $40 \%$ of the phosphate fertilisers used in the country (ANDA, 2015).

The correct management of mineral fertilisation is one of the main factors that maximise the production efficiency of the rocket crop (CECÍLIO FILHO et al., 2014). Because it is a shortcycle species, it requires a large amount of fertiliser per unit area, so it is very important to develop a balanced fertiliser program that provides adequate nutrient doses centred on the plants' growing conditions. In general, the fertilisation programs used for most crops are based on recommendation tables based on the response of plants grown in lownutrient soils, a factor that often does not match with the reality of farmers. In addition, most of the recommendation tables used for vegetable production are outdated, due to changes in the production system and the introduction of new technologies. Due to the intensive cultivation of vegetables, repeated fertilisation is frequent, increasing the nutrient accumulation in the soil. Among the nutrients, the concern with phosphorus (P) is relevant.

In the cultivation of the rocket, Trani, Passos and Azevedo Filho (1997) recommend $200 \mathrm{~kg} \mathrm{ha}^{-1}$ of $\mathrm{P}_{2} \mathrm{O}_{5}$, for soils with a high $\mathrm{P}$ content $(>60 \mathrm{mg}$ of $\mathrm{P} \mathrm{dm}{ }^{-3}$ of soil). However, it common to see farmers apply doses higher than the recommended, perhaps it occurs due to the outdated fertilisation recommendation and developments in crop management. Furthermore, phosphate fertilisation is considered low efficient in very weathered soils that are rich in clay minerals and iron/aluminium oxides, which strongly adsorb P (RAIJ, 1991; LI et al., 2017). This practice causes an increase in the accumulation of $\mathrm{P}$ in soils over the years, without increasing productivity, and this can cause serious problems, such as nutritional imbalance, environmental pollution, in addition to increasing production costs (LI et al., 2017; ZHANG et al., 2019).

So far, studies on nutrition and fertilisation of rocket in soils with high levels of $\mathrm{P}$ are rare. Studies with other Brassicas have shown that plants responded well to $\mathrm{P}$ fertilisers even in $\mathrm{P}$-rich soil (CECÍLIO FILHO; SILVA; MENDOZA-CORTEZ,
2013; CECÍLIO FILHO et al., 2015). Therefore, research on this topic could contribute to the improvement of official fertiliser recommendation tables for the rocket crop. Based on the above, the objective of this study was to evaluate the agronomic performance of rocket as a function of phosphorus fertilisation in a P-rich Rhodic Eutrudox soil.

\section{MATERIAL AND METHODS}

The experiment was conducted from 14 February to 24 March 2008, at São Paulo State University (UNESP), Jaboticabal campus, São Paulo, Brazil, $\left(21^{\circ} 15^{\prime} 22^{\prime \prime} \mathrm{S}, 48^{\circ} 15^{\prime} 58^{\prime} \mathrm{W}\right.$, and 575 m.a.s.l.). The overall average and means of minimum and maximum temperatures during the experimental period were $24.6 ; 19.8$ and $31.7^{\circ} \mathrm{C}$, respectively, and the relative humidity varied from 73.9 to $78.6 \%$. The soil of the experimental area is a typical Rhodic Eutrudox with a very clayey texture (SANTOS et al., 2013). A chemical analysis of the soil before to the experiment indicated a $\mathrm{pH}\left(\mathrm{CaCl}_{2}\right)$ of $5.6,25.0$ $\mathrm{g} \mathrm{dm}^{-3}$ of organic matter, $115.0 \mathrm{mg} \mathrm{dm}^{-3}$ of $\mathrm{P}$ (resin), $3.6 \mathrm{mmol}_{\mathrm{c}} \mathrm{dm}^{-3}$ of $\mathrm{K}, 38.0 \mathrm{mmol}_{\mathrm{c}} \mathrm{dm}^{-3}$ of $\mathrm{Ca}, 20.0$ $\mathrm{mmol}_{\mathrm{c}} \mathrm{dm}^{-3}$ of $\mathrm{Mg}, 25.0 \mathrm{mmol}_{\mathrm{c}} \mathrm{dm}^{-3}$ of $\mathrm{H}+\mathrm{Al}, 86.6$ $\mathrm{mmol}_{\mathrm{c}} \mathrm{dm}^{-3}$ cation exchange capacity and $71 \%$ base saturation of the soil. The P content in the soil was classified as high for the cultivation of vegetables (RAIJ et al. 1997).

The soil preparation consisted of ploughing and harrowing before the construction of the beds. According to the chemical analysis, it was not necessary to perform liming before planting, due to the high base saturation of the soil.

The treatments consisted of five doses of $\mathrm{P}$ $\left(0,50,100,200\right.$ and $\left.300 \mathrm{~kg} \mathrm{ha}^{-1} \mathrm{P}_{2} \mathrm{O}_{5}\right)$, tested in a randomised complete block design with four replicates. The phosphate fertiliser (triple superphosphate) was applied at planting and incorporated into the soil.

The total area of the experimental unit was $2 \mathrm{~m}^{2}$. The beds had eight rows, with spacing between rows of $0.25 \mathrm{~m}$ and $0.05 \mathrm{~cm}$ between plants within a row, totalling 160 plants per plot. For data collection, a harvest area of $1 \mathrm{~m}^{2}$ of the central rows was used, disregarding the first and last plants of each row. The rocket cultivar 'Folha Larga' was directly sown at the bed and thinned at 14 days after sowing (DAS) to adjust the spacing between plants to $0.05 \mathrm{~m}$.

At planting, nitrogen $\left(40 \mathrm{~kg} \mathrm{ha}^{-1} \mathrm{~N}\right)$ and potassium $\left(50 \mathrm{~kg} \mathrm{ha}^{-1} \mathrm{~K}_{2} \mathrm{O}\right)$ fertilisers were applied as recommended by Trani, Passos, and Azevedo Filho (1997), using urea and potassium chloride as the sources, respectively. Also, side-dress applications of $\mathrm{N}$ followed the recommendation of these authors, applying $40 \mathrm{~kg} \mathrm{ha}^{-1}$ of $\mathrm{N}$ (urea). The fertiliser was distributed along the rows about $5 \mathrm{~cm}$ apart without incorporating the fertiliser at 7,14 and 21 DAS. 
The crop was irrigated by sprinklers at a quota of $5 \mathrm{~mm} \mathrm{~d}^{-1}$, with a daily watering shift in the initial phase and thereafter every two days. Weeds were controlled by manual hoeing. Phytosanitary treatments were applied using products registered for the crop. The harvest was carried out by cutting the leaves at the base of the plant at 38 DAS.

The characteristics evaluated were a) the number of leaves per plant: obtained from 10 plants at harvest, b) height $(\mathrm{cm})$ : prior to harvest, $37 \mathrm{DAS}$, twenty plants were measured from the ground surface to the highest end of the foil, not extended, c) leaf area $\left(\mathrm{cm}^{2}\right.$ per plant): obtained at harvest, in ten plants, using a LICOR 3100 electronic meter, d) yield $\left(\mathrm{kg} \mathrm{m}^{-2}\right)$ : estimated based on the fresh mass of rocket determined immediately after harvest, e) $\mathrm{P}$ content in the newly developed leaf $\left(\mathrm{g} \mathrm{kg}^{-1}\right)$ which was determined at 25 DAS from collecting an intermediate leaf of ten plants of the harvest area of each plot. The leaves were then washed, dried, ground and prepared for determination of the $\mathrm{P}$ content, according to the methodology proposed by Miyazawa et al. (2009). f) P content in the shoot at 25 DAS (g kg-1) and harvest (g kg-1): at 25 DAS, one plant was randomly selected in each plot and at harvest (38 DAS), ten plants of the harvest area were selected for the determination of the shoot $\mathrm{P}$ content according to the methodology previously described and g) $\mathrm{P}$ content in the soil after harvest $\left(\mathrm{mg} \mathrm{dm}^{-3}\right)$ which was determined after the end of the experiment. Ten subsamples of soil were collected in the harvest area of each plot, in the 0 to $20 \mathrm{~cm}$ layer of the soil to form a composite sample, carrying out the determination of the nutrient according to the methodology described by Raij and Quaggio (2001).

Data were submitted to analysis of variance with an F-test at 5\% of probability using the AGROESTAT program

(BARBOSA; MALDONADO JÚNIOR, 2015). Regression analysis was performed of all characteristics evaluated, choosing the equation with the highest coefficient of determination and significant $(\mathrm{p}<0.05)$.

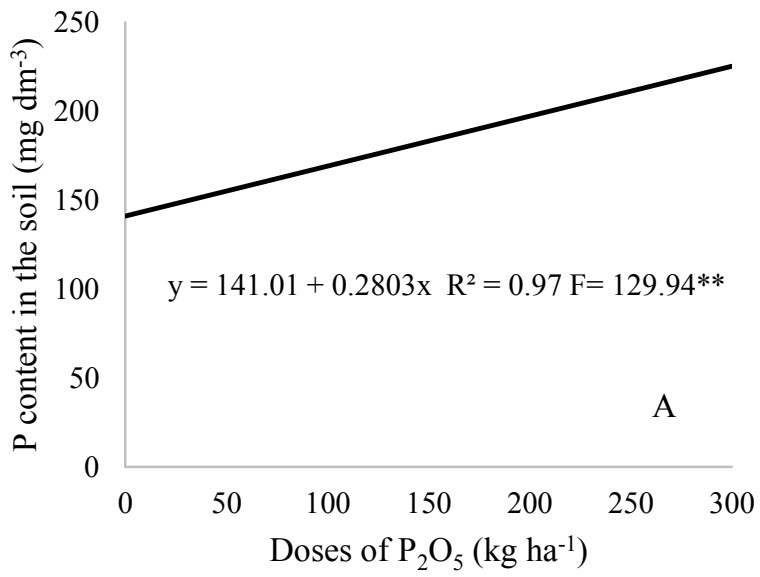

\section{RESULTS AND DISCUSSION}

Phosphate fertilisation influenced $\mathrm{P}$ content in the soil, $\mathrm{P}$ content in the shoots at harvest, plant height, and yield. The averages observed for the number of leaves, leaf area, P content in the newly developed leaves, and $\mathrm{P}$ content in the shoots at 25 DAS were $13.0 ; 522.0 \mathrm{~cm}^{2}$ per plant; $4.3 \mathrm{~g} \mathrm{~kg}^{-1}$; and $4.3 \mathrm{~g} \mathrm{~kg}^{-1}$, respectively. The lack of positive effect from phosphate fertilisation in most of the evaluated characteristics may be related to the very short cycle of the rocket and the high initial $\mathrm{P}$ content in the soil $\left(115 \mathrm{mg} \mathrm{dm}^{-3}\right)$, an amount sufficient to meet the plant requirements (GRANGEIRO et al., 2011). Plants grown in P-deficient soils respond well to phosphate fertilisation, with this response being less evident in soils with high nutrient content (WANG; LI, 2004, WANG et al., 2015).

The $\mathrm{P}$ content in the soil after harvest and $\mathrm{P}$ content in the shoot at harvest were both affected by phosphate fertilisation such that higher doses of $\mathrm{P}$ resulted in a linear increment in both variables (Figure 1A and 1B). The $\mathrm{P}$ content in the soil after harvest falls into the class of very high $\mathrm{P}$ content in the soil, according to the classification of Raij et al. (1997), which has a limit of $120 \mathrm{mg} \mathrm{dm}^{-3}$. The $P$ content in the soil after harvest increased linearly, reaching $225.10 \mathrm{mg} \mathrm{dm}^{-3}$ when the maximum dose of $\mathrm{P}_{2} \mathrm{O}_{5}\left(300 \mathrm{~kg} \mathrm{ha}^{-1}\right)$ was applied. For each $1 \mathrm{~kg}$ increase in the $\mathrm{P}_{2} \mathrm{O}_{5}$ dose, an increase of $0.2803 \mathrm{mg}$ $\mathrm{dm}^{-3}$ in the $\mathrm{P}$ content in the soil was observed. The results reported are similar to those of Deenik et al. (2006); Cecílio Filho, Silva, and Mendoza-Cortez (2013); and Cecílio Filho, Dutra, and Silva (2017), who also observed $\mathrm{P}$ contents in the soil after harvest $51 \%, 60 \%$, and $42 \%$, respectively, higher in the treatments which received the maximum dose of $\mathrm{P}$ than the treatments without application of the nutrient, when they evaluated the phosphate fertilisation in other species of Brassicas. Therefore, it is likely that in areas with intensive production of vegetables with the constant application of phosphate fertilisers, the accumulation of $\mathrm{P}$ in the soil will increase over the years.

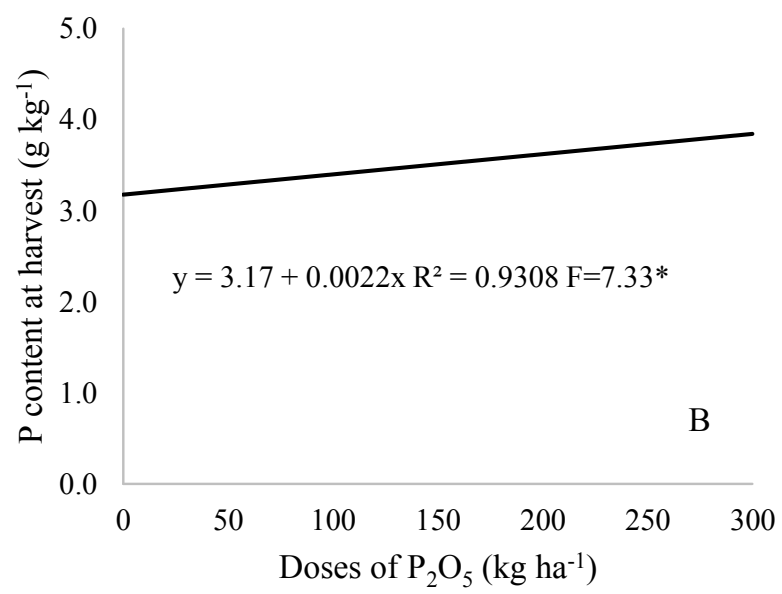

Figure 1. Phosphorus content in the soil (A) and phosphorus content at harvest (B) as a function of $\mathrm{P}_{2} \mathrm{O}_{5}$ doses.

Rev. Caatinga, Mossoró, v. 33, n. 3, p. 860 - 864, jul. - set., 2020 
The higher the dose of $\mathrm{P}$ applied, the greater was the $\mathrm{P}$ content in the shoot at harvest per plant. The $\mathrm{P}$ content in the shoot at harvest obtained with $300 \mathrm{~kg} \mathrm{ha}{ }^{-1}$ of $\mathrm{P}_{2} \mathrm{O}_{5}$ was $21 \%$ higher than that obtained in plants with no application of the fertiliser (3.2 to $3.8 \mathrm{~g} \mathrm{~kg}^{-1}$ ).

The height and yield of the rocket plants decreased linearly with the $\mathrm{P}$ doses (Figure 2). The high availability of $\mathrm{P}$ relative to the plant requirements, besides increasing the production costs, can generate several negative effects, such as nutritional imbalance, reduced efficiency in the use of $\mathrm{P}$, reduced plant development, yield and product quality (CARDOSO et al., 2016; CRUZ et al., 2016). Very high $\mathrm{P}$ concentrations in the soil can reduce the efficiency of absorption and utilisation of micronutrients, mainly zinc, but also to a lesser extent other nutrients, such as copper, iron, and manganese, leading to a decrease in the agronomic performance of the crop. This occurs due to the precipitation of $\mathrm{P}$ in the conductive vessels of the plants, making it difficult to transport micronutrients to the shoot and causing deficiencies (MALAVOLTA; VITTI; OLIVEIRA, 1997).

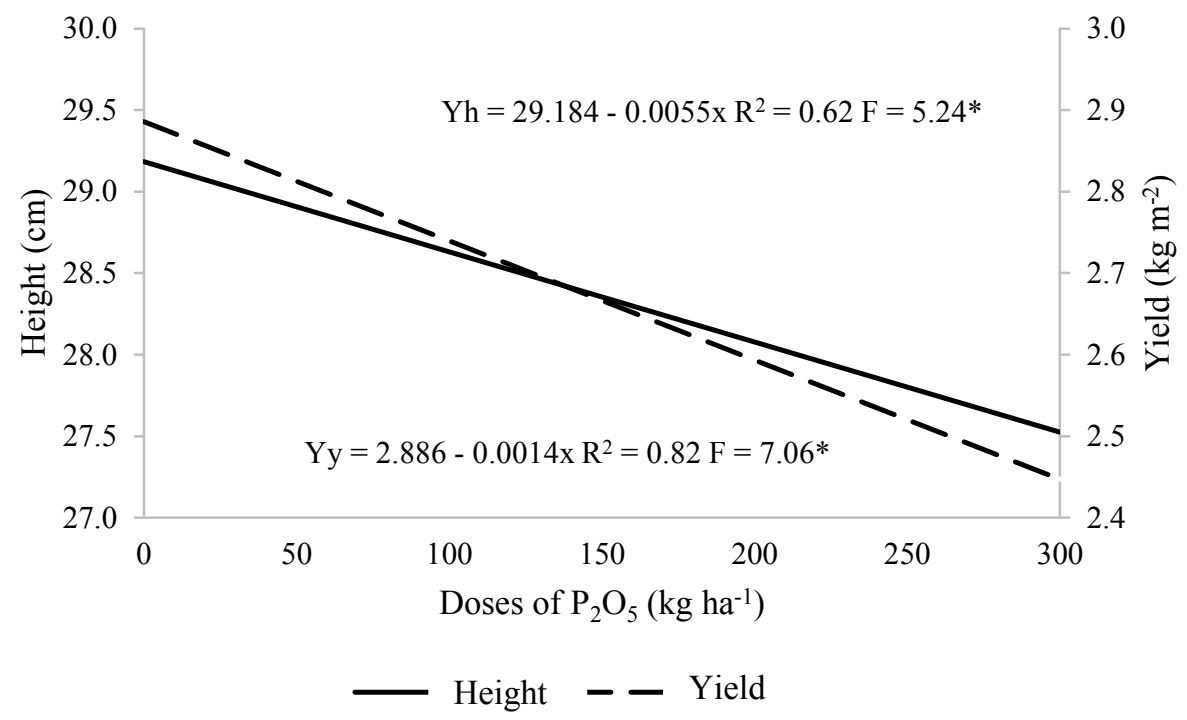

Figure 2. Height $(\mathrm{Yh})$ and yield $(\mathrm{Yy})$ of rocket plants as a function of $\mathrm{P}_{2} \mathrm{O}_{5}$ doses.

The decrease of yield is relevant to the farmer because, without the application of fertiliser under the conditions of this study, the production per hectare would be $28,860 \mathrm{~kg} \mathrm{ha}^{-1}$, compared to $26,060 \mathrm{~kg} \mathrm{ha}^{-1}$ obtained with the application of $200 \mathrm{~kg} \mathrm{ha}^{-1}$ of $\mathrm{P}_{2} \mathrm{O}_{5}$ as recommended by Trani, Passos and Azevedo Filho (1997). These values represent a $9.7 \%$ reduction in total production, that is, the farmer will lose $12,068.00$ per $\mathrm{R} \$$ ha, considering the average price of $4.31 \mathrm{R} \$$ per $\mathrm{kg}$ (CEAGESP, 2020). Besides the profit that the farmer will fail to earn with the decrease in yield, there will also be the cost of phosphate fertiliser, 1,339.60 R $\$$ per ton if a simple superphosphate source is used (IEA, 2019).

\section{CONCLUSION}

For a Rhodic Eutrudox soil with an available phosphorus content equal to or greater than $115 \mathrm{mg}$ $\mathrm{dm}^{-3}$, phosphate fertilisation should not be performed since it decreases the height and yield of rocket.

\section{REFERENCES}

ASSOCIAÇÃO NACIONAL DE DIFUSÃO DE ADUBOS - ANDA. Anuário estatístico. 2015. Disponível em: <http://anda.org.br/estatisticas $>$. Acesso em: 12 dez. 2019.

BARBOSA, J. C.; MALDONADO JÚNIOR, W. Experimentação Agronômica \& AgroEstat: Sistema para análises estatísticas de ensaios agronômicos. 1. ed. Jaboticabal, SP: Gráfica Multipress Ltda, 2015. 396 p.

CARDOSO, A. I. I. et al. Phosphate fertilization on production and quality of cauliflower seeds. Ciência Rural, 46:1337-1343, 2016.

CECÍLIO FILHO, A. B.; SILVA, S. G.; MENDOZA -CORTEZ, J. W. Phosphorus fertilization of 'Fuyutoyo' cabbages in phosphorus-rich Eutrustox soil. Chilean Journal of Agricultural Research, 73: 288-292, 2013 
CECÍLIO FILHO, A. B. et al. Épocas de cultivo e parcelamento da adubação nitrogenada para rúcula. Comunicata Scientiae, 5: 252-258, 2014.

CECÍLIO FILHO, A. B. et al. Cauliflower and broccoli productivity as influenced by phosphorus fertilizer doses in a P-rich soil. Australian Journal of Crop Science, 9: 709-7012, 2015.

CECÍlio FILHO, A. B.; DUTRA, A. F.; SILVA, G. S. Phosphate and potassium fertilization for radish grown in a latosol with a high content of these nutrients. Revista Caatinga, 30: 412-419, 2017.

CHUN, J. H. et al. Combined effect of nitrogen, phosphorus and potassium fertilizers on the contents of glucosinolates in rocket salad (Eruca sativa Mill.). Saudi Journal of Biological Sciences, 24: 436-443, 2017.

COMPANHIA DE ENTREPOSTOS E ARMAZÉNS GERAIS DE SÃO PAULO CEAGESP. 2020. Cotações - Preços no atacado: verduras. Disponível em: <http:// www.ceagesp.gov.br/entrepostos/servicos/cotacoes/ >. Acesso em: 26 jan. 2020.

COMPANHIA DE ENTREPOSTOS E ARMAZÉNS GERAIS DE SÃO PAULO CEAGESP. 2017. Guia Ceagesp: Rúcula. Disponível em: < http://www.ceagesp.gov.br/guiaceagesp/rucula-2/>. Acesso em: 22 mai. 2020.

CRUZ, S. M. C. et al. Mineral nutrition and yield of sweet potato according to phosphorus doses. Comunicata Scientiae, 7: 183-191, 2016.

DEENIK, J. et al. Phosphorus fertilizer management for head cabbage. Soil and Crop Management, 16: $1-6,2006$.

GRANGEIRO, L. C. et al. Crescimento e acúmulo de nutrientes em coentro e rúcula. Revista Brasileira de Ciências Agrárias, 6: 11-16, 2011.

INSTITUTO DE ECONOMIA AGRÍCOLA - IEA. Preços agrícolas. 2019. Disponível em: < http:// ciagri.iea.sp.gov.br/>. Acesso em: 01 nov. 2019.

LI, X. et al. Identification of soil $\mathrm{P}$ fractions that are associated with $\mathrm{P}$ loss from surface runoff under various cropping systems and fertilizer rates on sloped farmland. Plos One, 13: e0191753, 2017.

MALAVOLTA, E.; VITTI, G. C.; OLIVEIRA, S. A. Avaliação do estado nutricional das plantas: princípios e aplicações. 2. ed. Piracicaba, SP: Potafos, 1997. 319 p.
MIYAZAWA, M. et al. Análises químicas de tecido vegetal. In: SILVA, F. C. (Ed.). Manual de análises químicas de solos, plantas e fertilizantes. 2. ed. Brasília, DF: EMBRAPA, 2009. cap. 1, p. 190-223.

RAIJ, B. V. Fertilidade do solo e adubação. 1. ed. Piracicaba, SP: Potafos, 1991. 343 p.

RAIJ, B. V. et al. Recomendações de adubação e calagem para o estado de São Paulo. 2. ed. Campinas, SP: IAC, 1997. 285 p.

RAIJ, B. V; QUAGGIO, J. A. Determinação de fósforo, cálcio, magnésio e potássio extraídos com resina trocadora de íons. In: RAIJ B. van et al. (Eds.). Análise química para avaliação da fertilidade de solos tropicais. Campinas, SP: Instituto Agronômico, 2001. v. 1, cap. 11, p. 189199.

SANTOS, H. G. et al. Sistema brasileiro de classificação de solos. 3. ed. Brasília, DF: EMBRAPA, 2013. 376 p.

TRANI, P. E.; PASSOS, F. A.; AZEVEDO FILHO, J. A. Alface, almeirão, chicória, escarola, rúcula e agrião d'agua. In: RAIJ, B. van et al. (Eds.). Recomendação de adubação e calagem para o estado de São Paulo (Boletim Técnico, 100). 2. ed. Campinas, SP: Instituto Agronômico, 1997. cap. 18, p. 168-169.

WANG, Z.; LI, S. Effects of nitrogen and phosphorus fertilization on plant growth and nitrate accumulation in vegetables. Journal of Plant Nutrition, 27: 539-556, 2004.

WANG, R. et al. Phosphorus accumulation and sorption in calcareous soil under long-term fertilization. Plos One, 10: e0135160, 2015.

ZHANG, Y. et al. Optimizing phosphate fertilizer application to reduce nutrient loss in a mustard (Brassica juncea var. tumida)-maize (Zea mays L.) rotation system in Three Gorges Reservoir area. Soil and Tillage Research, 190: 78-85, 2019. 